Вестник ПСТГУ

Серия V. Вопросы истории

и теории христианского искусства

2015. Bun. 2 (18). C. 123-133

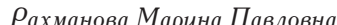

д- $р$ искусств.

вед. науч. сотр.

Государственного института искусствознания rmarina@mail.ru

\title{
ВЛАДИМИР ИВАНОВ-КОРСУНСКИЙ
}

\begin{abstract}
М. П. РАХМАHOBA
В статье идет речь о биографии и духовно-музыкальном творчестве забытого ныне композитора, одного из поздних учеников Балакирева, - Владимира Иванова-Корсунского. На основе документов прослеживается исполнение его церковных хоров в КнязьВладимирском соборе Петербурга (тогда - Ленинграда) в 1930-е годы. Приводится список духовно-музыкальных сочинений композитора, дан их краткий анализ.
\end{abstract}

С именем Владимира Митрофановича Иванова-Корсунского я впервые встретилась несколько лет тому назад, редактируя очередной альманах Трудов Музея музыкальной культуры имени Глинки (ныне - ВМОМК). В числе прочих материалов там публиковалась статья Татьяны Зайцевой под названием «Балакирев как педагог», где приводился ряд писем Милия Алексеевича к ИвановуКорсунскому, одному из его поздних частных учеников по композиции (с которыми, как известно, Балакирев занимался всегда бесплатно) ${ }^{1}$. Еще раньше, в 2004 г., в очередном балакиревском альманахе под редакцией Т. А. Зайцевой появилось сообщение об архиве Иванова-Корсунского, переданном в 1982 г. в Ленинградский государственный архив литературы и искусств (ныне ЦГАЛИ СПб). Там же приводилась и его Автобиография, составленная в 1922 г.

Владимир Митрофанович Иванов родился 23 мая 1881 г. в станице Эриванской Кубанской области в семье священника. Псевдоним «Корсунский» он взял по названию кубанской станицы Корсунской, где долгое время служил его отец. Далее цитирую Автобиографию:

«<..> Образование свое я получил в Екатеринодарском духовном училище и Ставропольской духовной семинарии. В г. Ставрополе я впервые мог удовлетворить свою потребность в музыке, возникшую еще в раннем детстве, но не встречавшую в родной семье благоприятных условий. К этому времени относятся мои первые произведения (романсы, хоры) и первоначальное знакомство с теорией <..> музыки, в чем я многим обязан учителю пения в семинарии В. Д. Беневскому, известному автору школьных хоров и церковных композиций.

По окончании семинарии в 1901 году вопреки настоянию отца и учебного начальства, направлявших меня в духовную академию, я поступил в б[ывший] Петербургский университет, где обучался на историко-филологическом

${ }^{1}$ Труды ГЦММК. Вып. 3. М., 2007. 
факультете. Попытка поступить в консерваторию не удалась, так как у меня не было средств для платы за обучение, и тогда я обратился к М. А. Балакиреву, находившемуся тогда уже в преклонных годах, который оказывал мне известное время и материальную поддержку, так как я сильно нуждался, и содействовал во многом моему музыкальному развитию, знакомя меня с выдающимися произведениями музыкальной литературы в собственной интерпретации, устраивая для меня посещение симфонических концертов и проч.» ${ }^{2}$.

Автор публикации справедливо замечает, что из переписки учителя и ученика следует: балакиревская опека не прекращалась ни во время отъездов ученика на летний отдых, ни после окончания им университета в 1907 г., когда он уехал из Петербурга в Новгород, где преподавал историю в средних учебных заведениях. Письма учителя к ученику (всего 70 писем - Музей имени Глинки. Ф. 39) ныне частично опубликованы в разных источниках, особенно подробно - в упоминавшейся статье Т. А. Зайцевой. Из писем, помимо прочего, ясно, что Корсунский не остался чужд революционным движениям в студенческой среде и все увещания Балакирева не могли изменить его взглядов. В 1907 г. Корсунский написал драматическую увертюру «Красное знамя», посвященную событиям 1905 г., причем сочинение это, судя по комментарию композитора в Автобиографии, было ему особенно дорого:

«1 декабря 1917 года симфоническим оркестром латышских стрелков под управлением Т. Рейтера была впервые исполнена моя увертюра “Красное знамя”, первое мое симфоническое произведение и едва ли не первое по времени отображение революции в русской музыке. В финал этой увертюры мною введен “Русский гимн свободы", сочиненный мною и нелегально напечатанный в 1905 году» ${ }^{3}$.

В январе 1925 г. Иванов-Корсунский переехал из Новгорода в Ленинград, где работал главным образом в вузах и на рабфаках и продолжал сочинять музыку. Композиторский список его достаточно велик: оперы «Сын народа», «Марфа Посадница», оперетты «Проделки герцогини», «Квартеронка», «Ночи Стамбула», музыкальная комедия «Гонведы», три симфонии, сюита «Дарьял (по ВоенноГрузинской дороге)», увертюры и фантазии для симфонического оркестра, трио для скрипки, виолончели и фортепиано, хоры, романсы, фортепианные пьесы.

Умер В. М. Иванов-Корсунский 3 февраля 1942 г. в блокадном Ленинграде, похоронен в братской могиле Серафимовского кладбища.

Однажды в петербургском музыкальном магазине мое внимание обратила на себя небольшая книжечка со знакомым лицом на обложке и титулом: «В. М. Иванов-Корсунский. Противостояние. Воспоминания. Дневники. СПб., 2006». Выяснилось, что ученица Т. А. Зайцевой, Карина Щирина, поработав с архивом Корсунского, опубликовала фрагменты его дневника, а в виде иллю-

\footnotetext{
${ }^{2}$ Цит. по: Ярошевская Виталия. Ученик М. А. Балакирева // Балакиреву посвящается / Ред.-сост. Т. А. Зайцева. Вып. 2. СПб., 2004.

${ }^{3}$ ЦГАЛИ СПб. Ф. 401. ОП. 1. № 161. Л. 14.
} 
стративного приложения дала ряд фотографий, и в их числе - факсимиле первых страниц двух духовных хоров. В комментарии указывалось:

«В ЦГАЛИ СПб сохранились две тетради духовно-музыкальных сочинений Корсунского: первая тетрадь озаглавлена "Всенощное бдение (Неизменяемые песнопения). Для смешанного хора" (1915); вторая тетрадь - “Духовномузыкальные сочинения Владимира Корсунского” - состоит из отдельных песнопений Божественной Литургии и Всенощного бдения, написанных в 1920-1930-е годы (ЦГАЛИ. Ф. 401. ОП. 1. № 73, 76)».

С 1 января 1934 г. и до октября 1936 г. Корсунский писал нечто вроде кратких воспоминаний о текущих событиях («Ежемесячные листы»), затем, с апреля 1936 г. до февраля 1937 г., вел дневник («Немного дневника»). Эти документы и были опубликованы с комментариями в книге «Противостояние». Я сделала выборку из них, которая получилась, на мой взгляд, хотя и краткая, но любопытная.

1934, 28 июля

Для Соловьева Ивана Семеновича ${ }^{4}$ сочинил три пьесы для его хора ко дню моего патрона Князя Владимира. Он их исполнял во время службы.

1935, апрель

На Пасху, 28-го, был на хорах во Владимирском соборе.

1935, июль

28-го (15-го старого стиля: именины Владимира) был в гостях Иван Семенович Соловьев. Все было очень скромно. Накануне слушал в его исполнении свою музыку.

1935 , сентябрь

8-го утром слушал у Князя Владимира «Не имамы» - очень понравилась.

1935, октябрь

13-го накануне Покрова у Князя Владимира исполняли четыре моих номера. Соло сопрано Е. А. Михайлова5

1936, март

Неожиданное появление на моем горизонте Коли Минкина (после 30 лет разлуки), его направил Иван Семенович [Соловьев], у которого он пел 6 .

\footnotetext{
${ }^{4}$ Иван Семенович Соловьев - регент Князь-Владимирского собора; судя по дневниковым записям, близкий приятель Корсунского.

${ }^{5}$ Михайлова-Войтон Евгения А. - лирико-драматическое сопрано, сотрудница Корсунского в его светских концертных выступлениях.

${ }^{6}$ Николай Николаевич Минкин - тенор; как явствует из текста, давний знакомый Корсунского; многократно упоминается в дневнике.
} 
1936, апрель

12-го была Пасха (у Заутрени с Колей ${ }^{7}$ у Князя Владимира на хорах). Первый раз (на Страстной) после 24-го года отговелся. Странно - стало легче на душе.

1936, июнь

Сочинил по просьбе Минкина «От юности» (соло тенора) 26-го и 27-го (вечером и утром). Вышло удачно.

1936

4 апреля. Домашние хлопоты. Музыка. Тоска воспоминаний. Вечером у Князя Владимира.

5 апреля. Вербное воскресение. Утром у Князя Владимира. Днем был Минкин, потом - Всенощная.

6 апреля. Вечером к Князю Владимиру.

21 мая. Вознесение. Служба под Николин день. «Благий рабе».

4 июля. Сочинил для Ивана Семеновича тропарь князю Владимиру по образцу тропаря Александровского Тамбовского роспева. Вечером передал.

27 июля. Вечером - у Князя Владимира. Пели семь моих номеров. Вышло удачно (слаба сопрано в соло «Величит»).

30 сентября. В 12 часов дня у Беневских казывал ему хоры. Ему все нравится. Отобрал 7 номеров.

19 октября. Пришел Васильев. Читал «Ни пера, ни пуха» и опять просит сделать музыку - бессмысленная затея. Пьеса - грубо цинична. Сверхсатира на духовенство.

12 ноября. Смотрел старые романсы Балакирева ${ }^{10}$. Изумительна «Песня Селима» и еще кое-что, но есть и слабые («Обойми, поцелуй»). Расстроился от музыки и мыслей о Балакиреве. Сидим без гроша, почти на одном хлебе.

\footnotetext{
${ }^{7}$ Николай Корсунский - младший сын Иванова-Корсунского, школьник.

${ }^{8}$ Сестры Беневские - Ольга Васильевна и Любовь Васильевна - дочери учителя Корсунского в Ставропольской семинарии Василия Дмитриевича Беневского. О. В. Беневская была педагогом, именно она сохранила архив как своего отца (ныне в Музее им. Глинки), так и Корсунского, который передал ей свои рукописи первой блокадной зимой (1942).

В. Д. Беневский (1864-1930) учился в казанских духовных школах, был регентом Ставропольского кафедрального собора, известным деятелем хорового образования. По инициативе Ольги Беневской в Ставрополе был открыт в 1960 г. музей, посвященный ее отцу и его ученикам, в том числе Корсунскому и К. К. Пигрову.

${ }^{9}$ Б. В. Боголепов, также ученик Беневского.

${ }^{10}$ Таким образом Корсунский начал личную подготовку к 100 -летию со дня рождения своего учителя.
} 
М. П. Рахманова. Владимир Иванов-Корсунский

1937

1 января. Днем к Беневским за портретом Балакирева. Потом к Комаровой [-Стасовой] - с трудом разыскал квартиру на 2-й Советской. Варвара Дмитриевна - прыткая, умная старуха. Неожиданно долгий разговор по поводу юбилея. Много рассказывал о себе. Условились относительно панихиды на 3-е число. От ней с портретами в редакцию «Красной газеты». <...>

2 января. Перед Иваном Семеновичем [Соловьевым] - в церкви Знамения - опоздал к началу всенощной. Сухой старик - регент Фатеев - по 7 рублей на человека за участие в хоре на панихиде. Ответил уклончиво. Сам Фатеев, кажется, из Капеллы. Изумительная алчность ${ }^{11}$.

3 января. День юбилея. К 10 часам в Филармонию поговорить с музыкантами. <...> Оттуда к Комаровой - как быть с хором? - решили отказаться. <..> В церковь к концу обедни. Отказ от хора. Пришла Комарова, ожидание, еще дама и позже Ляпунова с дочерьми. Панихида с одним священником в Серафимовском приделе.

7 января. Утром к ранней обедне.

11 января. Вечером в Консерватории был на концерте памяти Балакирева. Позорно мало народа (человек 40-50). Старуха Комарова, Ляпунова и ее дочери.

14 января. Утром к Князю Владимиру.

18 января. Вечером у Князя Владимира.

19 января. Днем у Князя Владимира (Крещение).

$$
* * *
$$

Публикация дневниковых записей Иванова-Корсунского, из которых следует, что в жестокие 1930-е годы в Ленинграде сочинялась и тут же исполнялась духовная музыка, стала стимулом к более подробному знакомству с духовномузыкальным творчеством композитора и с тем историческим контекстом, в котором оно возникло.

Прежде всего, любопытно, что, человек несомненно «левых» взглядов, Корсунский обратился к духовно-музыкальному жанру еще в Новгороде, в 1915 г., сочинив Всенощное бдение (неизменяемые песнопения) для смешанного хора. Неясно, была ли эта Всенощная адресована какому-либо конкретному хоровому коллективу, была ли она исполнена за службой. Неясно также, почему автор, довольно часто издававший в это время свои светские сочинения (романсы, фор-

${ }^{11}$ Василий Александрович Фатеев (1868-1942) действительно учился в Капелле, потом закончил Петербургскую консерваторию, в том числе по композиции у Римского-Корсакова. Известный духовный композитор, руководитель хора Казанского собора. В 1924 г. уехал в Новокузнецк. Выйдя на пенсию, вернулся в Ленинград, умер в блокаду. 
тепианные пьесы) за собственный счет, не попытался напечатать Всенощную. Просмотр выходившего в Новгороде до 1914 г. весьма содержательного духовнохорового журнала «Гусельки яровчаты» (под редакцией известного хорового деятеля, регента и композитора А. М. Покровского) не дал никаких сведений о контактах Корсунского в церковно-певческой среде: он упоминается только как педагог истории в мужской и женской гимназиях, устроитель гимназических концертов, автор исполнявшихся в них светских сочинений. Между тем, Новгород был в это время крупным певческим центром, где имелись хорошие хоры и опытные регенты, исполнявшие (судя хотя бы по приводимым в том же журнале программам духовных концертов и отдельных служб) разнообразный репертуар, включавший произведения современных авторов, в частности А. А. Архангельского и композиторов «синодальной школы». В Новгороде в это время архиепископом был владыка Арсений (Стадницкий), выдающийся литургист и знаток церковного пения, уделявший исключительно много внимания хоровому образованию.

Следующие даты в списке духовных сочинений Корсунского относятся также к новгородскому периоду: это Херувимская песнь для трехголосного мужского хора (1919), «Хвалите имя Господне» № 2 (1924). Дальнейшие 18 номеров связаны уже с Ленинградом: 1925-1937.

Поскольку дневниковые записи Корсунского охватывают только период 1934-1936 гг., то только по отношению к сочинениям этих лет можно говорить об обстоятельствах их появления. Однако уже в 1927 г. появляется сочинение («Сподоби, Господи» № 2), адресованное тому самому регенту Князь-Владимирского собора Ивану Семеновичу Соловьеву, с которым связаны и дальнейшие композиции. Из сопоставления дневника и дат на рукописях ясно также, что в подборке имеются не все духовные сочинения Корсунского. Например, по отношению к июлю 1934 г. в дневнике говорится о трех пьесах, сочиненных к храмовому празднику собора (и именинам Корсунского), а налицо только одно сочинение с такой датой - «Величит душа моя Господа» для сопрано с хором. В сентябре 1935 г. Корсунский упоминает исполнение в соборе своего «Не имамы», среди сочинений такового вообще нет, а данным месяцем обозначена литийная стихира на Воздвижение.

Трудно с уверенностью назвать причину подобных расхождений. Однако, глядя на рукопись подборки, которую, напомним, композитор отнес своей близкой знакомой первой зимой блокады, можно утверждать, что она не составлена из рукописей разных лет, а, скорее всего, написана подряд, «в один прием». Возможно, автор отобрал те композиции, которые считал более ценными, а может быть, имел копии или черновики не всех своих композиций, ибо они часто исполнялись в соборе буквально «из-под пера». Этому соображению не противоречит наличие незаконченных сочинений: думается, что при их записи автор, не имея полного оригинала, пытался вспомнить свой текст.

Любопытен психологический контекст этого духовно-музыкального творчества.

Корсунский в 1930-е гг. живет исключительно трудной в материальном и нравственном отношениях жизнью. В течение многих лет преподавая в разных 
М. П. Рахманова. Владимир Иванов-Корсунский

учебных заведениях города предмет под названием «История классовой борьбы», он в конце концов оставляет во 2-й пол. 1930-х гг. педагогику, пытаясь прожить творческими работами, а на самом деле - живет на мизерную пенсию, на небольшие гонорары (авторские отчисления), получаемые в Горкоме композиторов (нечто вроде Музфонда, в Союз композиторов Корсунский был принят только в 1940 г.), а также на случайные деньги, получаемые за концертные выступления с певцами в качестве аккомпаниатора, отдельные лекции в клубах и мелкие композиторские работы по заказу исполнителей. Вместе с Владимиром Митрофановичем живет его младший сын Николай - школьник средних классов, и в дневнике часто встречаются записи: нет денег на покупку ботинок сыну, сидим только на хлебе. Отношения с двумя старшими сыновьями, живущими самостоятельно, складываются не гладко. Корсунский пытается продвигать свои большие произведения, в частности симфонию, обращаясь с письмами и лично в разные инстанции, - но безуспешно. При этом он довольно много работает как композитор в разных жанрах, стремится регулярно посещать интересные концерты (давая в своем дневнике весьма грамотные оценки музыке и исполнителям), нередко играет свои произведения в домах друзей и знакомых.

Корсунский оказался единственным человеком, который в дни 100-летия со дня рождения Балакирева, т. е. в 1937 г., озаботился церковным поминовением композитора. С певчими договориться не удалось - оказалось слишком дорого, а денег у Корсунского было в обрез; отслужили без пения и совсем скромно: присутствовали только сам Корсунский, а также Варвара Дмитриевна КомароваСтасова и члены семьи другого - уже давно покойного - ученика Балакирева, Сергея Ляпунова (мать и две дочери). Представим себе этот день -7 января 1937 г.: панихида с одним священником в пустом храме и вечером концерт в филармонии, на котором присутствовало не более полусотни человек...

В нравственном отношении кроме безденежья и неустроенного быта его терзают мысли о жене Марии Ивановне (в девичестве Ефимовой), скончавшейся в Новгороде в 1924 г., причем из дневника понятно, что с ее кончиной связаны какие-то трагические обстоятельства (возможно, это было самоубийство). Корсунский часто видит жену во сне и молится за нее в храме. Не радуют его и судьбы других родственников, разъехавшихся по всей стране братьев и сестер. Корсунский пытается «соответствовать» текущим событиям (например, пишет песни на газетные тексты, посвященные войне в Испании), но отклика в «инстанциях» эта его деятельность тоже не находит ${ }^{12}$. Неизвестно, как долго оставался он при тех «левых» взглядах, с которыми пытался воевать в своих письмах Балакирев. Но что эти взгляды существенно изменились в 1930-е гг., представляется очевидным: текущая действительность Корсунскому явно очень не нравится, хотя он и готов выполнить «социальный заказ».

${ }^{12}$ Единственный романс Корсунского советской эпохи под названием «Сатиновая кофточка», найденный среди изданий его сочинений в РГБ (все остальное - издания до 1917 г.), представляет собой значительное упрощение стиля композитора в духе городской песни, но без всякой пошлости и «эстрадности»; примечательно, что фильм «Веселые ребята» показался Корсунскому при просмотре невыносимо пошлым. 
На таком фоне встает вопрос о причинах обращения Корсунского к духовному творчеству. Вероятно, друг-регент платил ему какие-то деньги за композиции, написанные для хора Князь-Владимирского собора. Однако, скорее всего, причина их возникновения была не только материальная: в дневнике есть записи о говении (первом за много лет) и причастии.

Приходят на память строки из письма Балакирева к Корсунскому, относящиеся к 1902 г. и тогдашним событиям в общественной жизни России:

«Блажен тот, кто все эти ужасные испытания выдержит, не упав нравственно. Но как это трудно! И возможно только при особенной помощи Божией» ${ }^{13}$.

Трудно судить определенно о стиле не звучащей музыки. Однако можно утверждать, что, во-первых, это не тривиальная сугубо «клиросная» музыка и вместе с тем не музыка специфически «концертная», а во-вторых, автор ее принадлежит к петербургской школе в широком понимании этого термина.

Разумеется, Корсунский - сын священника, выпускник духовной семинарии, ученик Беневского - прекрасно знал службу и церковно-певческий обиход. Не мог не знать он и новых веяний в этой области. Однако «московское» влияние его коснулось мало. Петербургская школа чувствуется в преимущественно, хотя и не исключительно, гармоническом складе письма, а в некоторых (немногих) песнопениях - в применении приемов, типичных для «капелльского» стиля: фанфарного типа ходов, пунктирного ритма. При всем том стиль Корсунского не похож, например, на стиль такого популярного петербургского автора, как А. А. Архангельский.

С одной стороны, Корсунский стремится избежать прямой «романсовости», сентиментальности. С другой стороны, его не тянет к архаическим интонациям в духе старинных роспевов. И даже в тех редких случаях, когда он берется за гармонизацию гласовых песнопений или применяет в своих композициях отдельные гласовые попевки, - это не ординарная гармонизация. Реально присутствует в музыке Корсунского традиция церковной псалмодии, временами достаточно ярко выступают элементы народного духовного пения, и это, на наш взгляд, самые удачные песнопения. Таковы, например, «Хвалите имя Господне» № 2 с изящным припевом «Аллилуиа», запричастен «К Богородице прилежно».

Безусловно, сильнее всего чувствуется школа Балакирева - не церковных композиций последнего, а общего метода: это сказывается во внимании к смыслу слова, к просодии, к декламации в целом, а также в способе развития исходного материала путем его высотного перемещения, в насыщенных красочных модуляциях, нередко энгармонических, в излюбленные Балакиревым многобемольные или многодиезные тональности. Во Всенощной таких приемов не очень много, в более поздних сочинениях они встречаются чаще, вплоть до злоупотребления ими.

В соответствии с привычками клиросного городского пения той эпохи, и соборного в особенности, Корсунский часто применяет солирующий голос или

\footnotetext{
${ }^{13}$ Альманах. С. 581.
} 
включает сольные партии разных голосов и их групп в хоровую партитуру. Из дневниковых записей ясно, что эти произведения сочинялись в расчете на голоса конкретных певцов и даже прямо по их заказу. Некоторые хоры с солистами представляются удачными - например, «Во Царствии Твоем» для баритона с хором, где «ариозная» сольная партия написана сдержанно, в традициях настоящей «русской школы». Не чуждо Корсунскому и стремление к тембровой красочности, чему примером может быть красивое «Достойно есть» (из Литургии) с имитацией колокольного перезвона в конце песнопения.

Вообще, во многих песнопениях этого автора есть ощущение речи «от первого лица», искренности выражаемого чувства. Иначе говоря, Корсунский идет не только от традиции «озвучивания» того или иного текста, сложившейся в композиторской практике его времени, но и от личного прочтения смысла текста, на который сочиняет. Показательный тому пример - не датированное (но по расположению в подборке, скорее всего, еще новгородского периода) песнопение, озаглавленное автором «Покаянная песнь» («Покаяния отверзи ми двери»): очень напряженное, до чрезмерности экспрессивное и субъективное.

Можно, вероятно, говорить и о некоторой эволюции духовного творчества Корсунского: Всенощное бдение в целом проще и, если можно так выразиться, нейтральнее, чем более поздние сочинения, из которых хронологически последнее, «Милость мира» № 2, датируется августом 1937 г. Было ли написано что-либо позже этой даты, трудился ли далее в соборе регент Соловьев - пока неизвестно.

Примечательно, что первое хронологически произведение Корсунского, написанное для соборного хора и регента Соловьева, относится к апрелю 1927 г. Как раз тогда собор, который в 1922-1926 гг. был захвачен обновленческой «Живой церковью» и конкретно - главой живоцерковников Владимиром Красницким (служившим в соборе с 1912 г.), перешел к Православной Церкви. В 1937 г. тяжелые репрессии обрушились на соборное духовенство: были расстреляны настоятель храма епископ Череповецкий Тихон (Рождественский), протоиерей Михаил Долотов, протодиакон Иоанн Гонестов. Но собор не был закрыт, и вплоть до 1941 г. он оставался кафедрой митрополита Ленинградского Алексия (Симанского). Если уцелел хор, то, вполне возможно, звучали в эти годы в соборе и сочинения Владимира Иванова-Корсунского.

Ключевые слова: православное церковное пение советской эпохи, Ленинград, 1930-е годы, Владимир Иванов-Корсунский.

\section{Список сочинений В. М. Иванова-Корсунского по материалам ЦГАЛИ СПб}

\section{Ф. 401. ОП. 1. № 73}

Всенощное бдение (неизменяемые песнопения) для смешанного хора, 1915 год.

1. Благослови, душе моя, Господа

2. Блажен муж 
Исследования

3. Вечерняя песнь «Свете тихий»

4. Ныне отпущаеши

5. Богородице Дево

6. Хвалите имя Господне № 1

6а. Хвалите имя Господне № 2

Ремарка автора: «Этот № выделен как № 1》

6б. Хвалите имя Господне № 3

7. Тропари по непорочных

8. Антифоны «От юности моея»

9. Песнопения по Евангелии

10. Катавасия рядовая «Отверзу уста моя»

11. Песнь Богородицы «Величит душа моя Господа»

12. Слава и ныне. Преблагословенна еси

13. Великое славословие

14. Взбранной Воеводе

Покаянная песнь. Сочинение Вл. Корсунского для смешанного хора «Покаяния отверзи ми двери» (без даты).

Херувимская песнь для трехголосного мужского хора. Соч. 21 ноября 1919. Утро Введения.

Малое славословие для смешанного хора. Соч. 5 февраля 1931.

Во Царствии Твоем для баритона соло и хора. Соч. 1-2 февраля 1931.

(Записана только первая строфа.)

Ф. 401. ОП. 1. № 76

( Нумерация автора, прерывающаяся на № 3.)

1. «Сподоби, Господи» для смешанного хора. 3 апреля 1925. Не закончено

2. «Хвалите имя Господне» № 2. Соч. 2 октября 1924

3. «Сподоби, Господи» № 2. Соч. 28 апреля 1927 для И. С. Соловьева

Во Царствии Твоем (для Литургии; для баритона соло с хором). 1-2 февраля 1931.

Малое славословие (с баритоном соло). Соч. 5 февраля 1931.

Запричастен (из Литургии) «К Богородице прилежно». Соч. 8 февраля 1931.

Достойно есть (из Литургии). Соч. 9 февраля 1931.

Воскресный тропарь «Днесь спасение миру бысть» № 1. Соч. 2 июля 1933.

То же № 2. Соч. 3 июля 1933.

Тропарь «Воскрес из гроба» № 2.3 июля [1933?].

Тропарь «Воскрес из гроба» № 1.

Тропари воскресны «Ангельский собор» Ремарка автора: «Могут быть исполняемы как запричастен». Октябрь 1933. 
М. П. Рахманова. Владимир Иванов-Корсунский 1934.

Величит душа моя (Песнь Богородицы) для сопрано соло с хором. 27 июля

Радуйся, живоносный Кресте. Литийная стихира на Воздвиженье (по 5 гласу). 20 сентября 1935.

Наста днесь пресветлый праздник. Литийная стихира Покрову Пресвятой Богородицы (на 3 глас).

«От юности моея» для смешанного хора с тенором соло. Соч. 26-27 июня 1936.

Многолетие для смешанного хора. 8 июля 1936 в 10 часов вечера. Ремарка автора: «По просьбе Ивана Семеновича».

«Милость мира» № 2.22 и 24 августа 1937.

\section{VLADIMIR IVANOV-KORSUNSKY}

\section{RAKHMANOVA}

The article focuses on the biography and church compositions of now-forgotten composer Vladimir Ivanov-Korsunsky, the private pupil of Balakirev in his later years. On the basis of the archive documents we show the perfomances of his church compositions in the Knyaz-Vladimir Cathedral in St. Petersburg (in those years - Leningrad) during $1930^{\text {th }}$. The article includes a list of church works and brief analysis of Ivanov-Korsunsky' style.

Keywords: Orthodox Church Chant, Soviet Period, Leningrad, 1930"th Vladimir Ivanov-Korsunsky.

\section{Список литературы}

1. Зайцева T. Балакирев как педагог // Труды ГЦММК имени М. И. Глинки. Альманах. Вып. 3. М., 2007.

2. Щирина К. В. М. Иванов-Корсунский. Противостояние. Воспоминания. Дневники. СПб., 2006.

3. Ярошевская В. Ученик М. А. Балакирева // Балакиреву посвящается / Ред.-сост. Т. А. Зайцева. Вып. 2. СПб., 2004. 